\title{
Analisa Metode Handover Pada Jaringan WiMAX
}

\author{
Murhaban*1 $^{1}$, Ahmad Ashari ${ }^{2}$ \\ ${ }^{1}$ Program Studi Teknik Industri, F.Teknik, Universitas Teuku Umar \\ ${ }^{2}$ Jurusan Ilmu Komputer dan Elektronika, FMIPA UGM, Yogyakarta \\ e-mail: ${ }^{* 1}$ murhabani@gmail.com, ${ }^{2}$ ashari@ugm.ac.id
}

\begin{abstract}
Abstrak
Metode Handover digunakan untuk mempertahankan koneksi tetap terjaga. Hal tersebut berkaitan dengan performansi dikarenakan proses pengalihan kanal trafik secara otomatis pada mobile station untuk berkomunikasi tanpa terjadinya pemutusan hubungan. Faktor utama keberhasilan dalam melakukan handover terletak pada quality of service yang menyediakan tingkat jaminan layanan berbeda-beda dalam mengatur dan memberikan prioritas trafik pada jaringan seperti aplikasi voice over IP (VoIP) atau komunikasi voice memanfaatkan jaringan internet.

Penelitian ini menganalisis kinerja quality of service pada jaringan WiMAX standar 802.16e menggunakan metode hard handover dan softh andover dengan aplikasi VoIP pada mobile station.

Berdasarkan pengujian yang dilakukan untuk metode hard handover dan metode soft handover menggunakan aplikasi voice over internet protocol pada mobile station. Diperoleh hasil dengan nilai jitter $0.001 \mathrm{~ms}-0.31 \mathrm{~ms}$, dan hasil delay $10,5 \mathrm{~ms}-39 \mathrm{~ms}$ hal tersebut membuktikan bahwa pengaruh jitter dan delay terhadap handover dengan aplikasi VoIP masih dalam tahapan toleransi yang diizinkan. Berbeda dengan output throughput 85 Bit/detik - 550 Bit/detik terlalu rendah dan mengindikasikan bahwa throughput tidak sentitif terhadap handover dengan aplikasi voice over internet protocol.
\end{abstract}

Kata kunci-Wimax, handover, hard handover, soft handover, VoIP

Handover method is used to keep the stabilization of connection. Its connected with the performance was caused the process canal traffic transfer automatically in mobile station (MS) that was used to communicate without cutting off the connection. The main factor of success in handover was quality of service to provide the difference level of service in arranging and giving the traffic priority in the network like voice over IP (VoIP) application or communication voice using internet network.

This research will analyse the achievement quality of service in the WiMax network standard 802.16e used hard handover and softhandover method with the VoIP application in mobile station.

Based on the testing that was carried out hard handover and soft handover method used the application of voice over internet protocol in mobile station has obtained value jitter 0.001 Ms $-0.31 \mathrm{~ms}$, and delay $10.5 \mathrm{~ms} 39 \mathrm{~ms}$ this is proved that the influence of jitter and delay against handover with the VoIP application still in the tolerance stage that was permitted. It is different with the output throughput 85 Bit/Sekon - 550 Bit/Sekon that is too low and indicated that throughput is not sentitif against handover with the voice over internet protocol application.

Keywords - Wimax, handover, hard handover, soft handover, VoIP 


\section{PENDAHULUAN}

$B$ roadband wireless access (BWA) dengan teknologi worldwide interoperability for microwave access (WiMAX), merupakan salah satu teknologi akses nirkabel pita lebar (broadband wireless access atau disingkat $B W A$ ) yang memiliki kecepatan akses yang tinggi dengan jangkauan yang luas. WiMAX sendiri mengacu pada standar yang dikeluarkan oleh institute of electrical and electronics engineering (IEEE) yaitu 802.16, standar tersebut terus dikembangkan dengan varian-varian yang memiliki keunggulan pada penggunaan atau kondisi tertentu diantaranya varian 802.16a, 802.16rev.d-2004, dan 802.16e [1].

Dalam perkembangannya terdapat beberapa masalah yang sering terjadi jaringan WiMAX. Salah satu diantaranya adalah handover (penyerahan) untuk mempertahankan koneksi tetap terjaga dengan menggunakan aplikasi voice over internet protocol (VoIP). Dimana handover merupakan hal penting yang berkaitan dengan performansi, dikarenakan proses pengalihan kanal traffic secara otomatis pada mobile station $(M S)$ yang sedang digunakan untuk berkomunikasi tanpa terjadinya pemutusan hubungan [2].

Faktor utama keberhasilan dalam melakukan proses hard handover dan soft handover dengan aplikasi user VoIP terletak pada quality of service (QoS). Tugas dari QoS untuk menyediakan tingkat jaminan layanan yang berbeda-beda untuk mengatur dan memberikan prioritas trafik pada jaringan seperti voice over IP (VoIP) atau komunikasi voice memanfaatkan jaringan internet. Aplikasi tersebut sangat dipengaruhi oleh jitter dan delay. Sehingga tujuan akhir dari QoS untuk memberikan network service yang lebih baik dan terencana dengan dedicated bandwidth, jitter dan latency yang terkontrol dan meningkatkan loss karakteristik [3].

Kestabilan dalam memberikan quality of service untuk layanan VoIP merupakan suatu tantangan yang besar untuk komunikasi berbasis IP dan internet secara keseluruhan, di mana $Q o S$ seharusnya dapat membantu end user (client) menjadi lebih produktif dengan memastikan bahwa user mendapatkan performansi yang baik. Dengan service class yang disediakan QoS yaitu unsolicated grant service (UGS), real time polling service (RTPS), non real time polling service (nRTPS), extended real-time polling service (ertPS) dan best effort (bE) [4].

\section{METODE PENELITIAN}

\subsection{Rancangan Penelitian}

Penelitian ini akan merancang sebuah model jaringan WiMAX dan mensimulasikannaya. Nodenode yang akan di implementasikan yaitu server, IP backbone, base station, dan mobile station (user). Dimana fungsi dan peran masing-masing node tersebut dalam mengirim dan menerima paket data akan sangat berpengaruh pada hasil yang akan di dapat, berikut fungsi dari setiap node yang dirancang.

A. Server

Untuk memberikan paket data sesuai dengan permintaan layanan dari service voice over internet protocol, yang selanjutnya paket data sebesar $64 \mathrm{Kbps}$ (standar G.711) akan dikirim untuk melayani permintaan layanan voice over internet protocol ketika melakukan mobiltasnya [5].

B. Backbone

Sebagai perantara atau penghubung antara server dan base station, agar kedua node tersebut dapat berkomunikasi dalam mengirim paket data, serta dapat berkomunikasi untuk melakukan perintah-perintah ketika mobile melakukan handover.

C. Peran base station sebagai pengirim dan penerima (transceiver) sinyal komunikasi dari/ke MS yang menyediakan radio interface antara MS, karena fungsinya sebagai transceiver, maka bentuk fisik sebuah BS adalah tower dengan dilengkapi antena sebagai transceiver

IJCCS Vol. 10, No. 1, January 2016: $59-70$ 
D. Mobile station melakukan komunikasi dengan base station yang terdiri dari terminal yang disebut mobile equipment dan pengguna yang disimpan pada kartu subcriber identity module (SIM).

\subsection{Mobiltas Mobile Station dengan Aplikasi VoIP dan Handover}

Skenario mobilitas mobile station akan dirancang untuk melewati delapan base station, dengan trajectory (rute) melewati base station hanya one way (satu arah) sesuai rekomendasi ITU-T [6]. Konsep cell base station akan digunakan dengan model cell hexagonal dikarenakan cell hexagonal dinilai lebih efektif karena sebuah hexagonal dibentuk oleh 6 buah segitiga sama sisi. Sehingga jarak sisi-sisinya dan jarak jari-jari selnya akan sama panjang dan dapat mengatasi masalah blank spot dan overlap coverage, seperti pada Gambar 1.

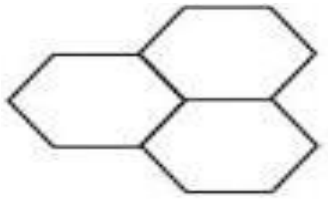

Gambar 1 Bentuk cell hexagonal

Mobilitas mobile station dimulai dari serving BS dan melewati BS target sesuai dengan trajectory (rute) yang telah ditentukan. Trajectory ini diperlukan agar mobile station mengetahui area yang harus dilewati, serta akan melakukan handover ketika memasuki area service sinyal dari serving BS berkurang dan melakukan pengalihan ke area service sinyal BS target. Hal ini diperlukan agar komunikasi antara base station dan mobile station dengan aplikasi VoIP tidak terputus seperti pada Gambar 2.

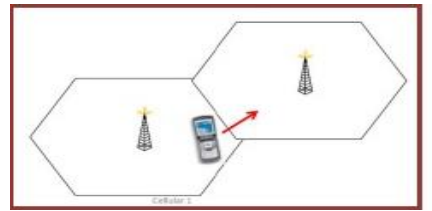

Gambar 2 Mobile station melakukan handover

Penentuan handover ketika mobile station melakukan mobilitasnya akan menggunakan dua metode yaitu metode hard handover dimana ketika terjadinya peralihan sinyal antara serving BS ke BS target, dalam penerapannya serving BS akan memutuskan lebih dahulu komunikasi dengan mobile station sebelum mobile station membangun komunikasi dengan BS target atau dikenal dengan "break-before-make". Sedangkan metode soft handover ketika melakukan peralihan service untuk mobile station, serving BS dan BS target dapat bekerjasama terlebih dahulu sebelum layanan dari serving $B S$ diputuskan dan motode ini masuk dalam tipe "make before-break connection" [2].

Tahap-tahap ketika mobile station melakukan mobilitas dan akan terjadinya proses handover.

1. Tahap Pengukuran dilakukan untuk mengukur informasi (sinyal) yang dibutuhkan selama mobile station (VoIP) melakukan mobilitas (menurut kecepatan dan batasan coverage area), selanjutnya informasi sinyal tersebut diberikan ketahap berikutnya.

2. Tahap Keputusan, hasil pengukuran sebelumnya akan diputuskan apakah mobile akan melakukan handover atau tidak melakukan handover.

3. Tahap Eksekusi, proses handover pada tahap ini akan dilakukan dengan menggunakan metode hard handover (kecepatan $<60 \mathrm{~km} / \mathrm{jam}$ ) dan metode soft handover (kecepatan $>60$ $\mathrm{km} / \mathrm{jam}$ ). Sehingga diperoleh hasil throughput, delay dan jitter. Berikut alur sistem handover pada Gambar 3. 


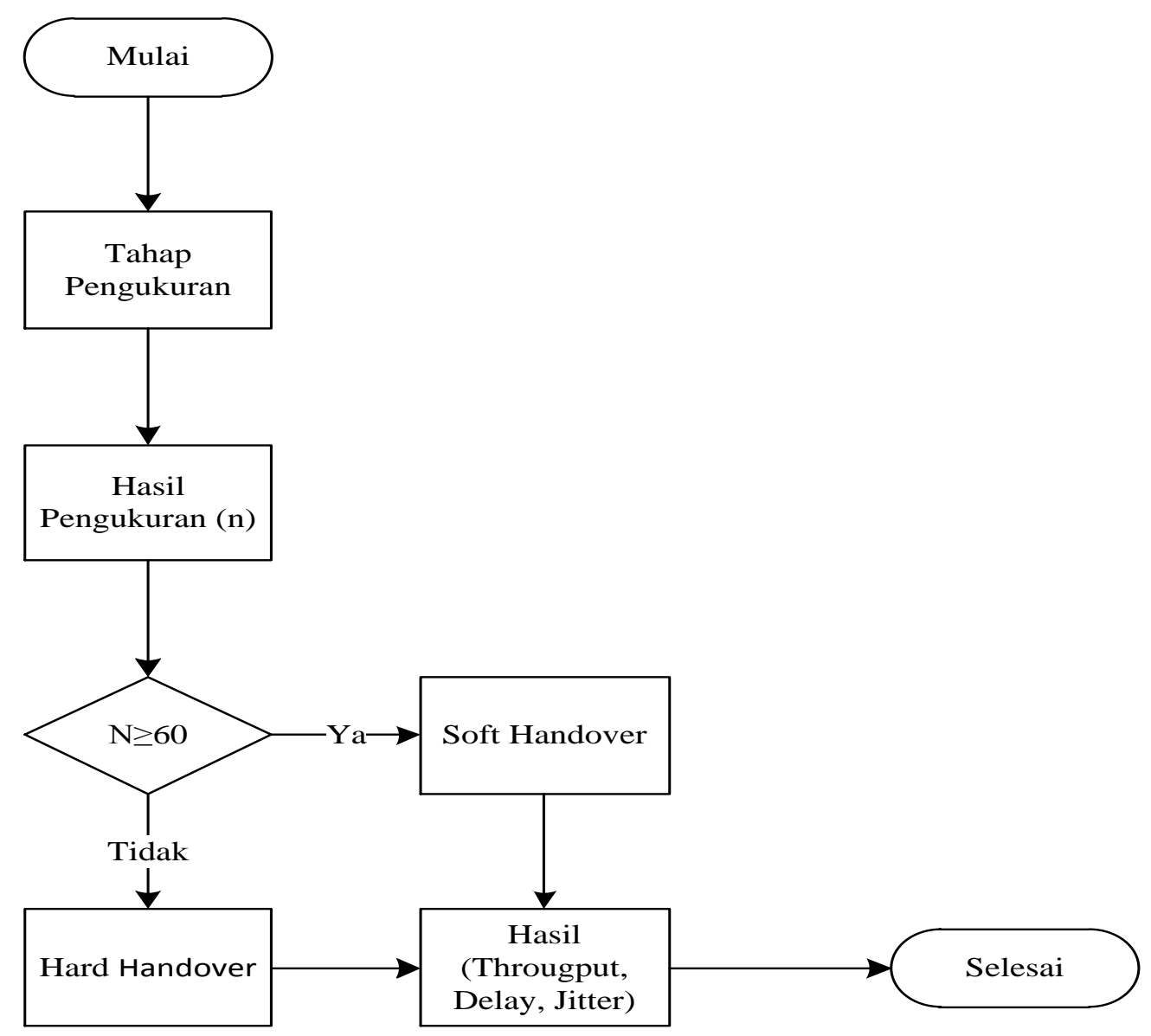

Gambar 3 Tahapan Proses Handover

\subsection{Rancangan Pengujian}

Berdasarkan rumusan masalah Sub Bab I, maka rancangan pengujian dalam penelitian ini akan menggunakan dua metode handover yaitu metode hard handover dan soft handover dengan aplikasi user VoIP. Masing-masing metode akan menggunakan tiga skenario pengujian dan dilakukan hanya sekali jalan (searah) dengan arah berlawanan jarum jam, dan mobile station dengan layanan voice over internet protocol akan melewati 8 Taget BS. Dalam pengujian ini hanya akan menggunakan frekuensi kerja (frekuensi band) $2.5 \mathrm{GHz}$ (lisensi WiMAX Forum), dengan quality of service yang menggunakan kelas layanan real time polling service dimana kelas layanan ini mendukung aliran service real-time untuk membangkitkan paket data variable-size, efektif untuk layanan yang sensitif terhadap throughput, delay (latency) dan jitter namun dengan toleransi yang lebih longgar bila dibandingkan dengan $U G S$.

Setiap skenario yang disimulasi menggunakan simulator OPNET Modeler 14.5 educational, akan dilakukan running berdurasi 20 menit dengan codec yang paling umum digunakan untuk aplikasi layanan voice over internet protocol yaitu codec G.711 dan menggunakan PCM untuk digitalisasi suara.

Skenario handover yang menggunakan metode hard handover dan soft handover akan divariasikan kecepatan mobile station dan jarak jangkauan base station. Setiap skenario akan dilakukan pengujian sebanyak tiga kali, dengan pengujian pertama menggunakan satu user, pengujian kedua menggunakan 3 user dan pengujian terakhir akan menggunakan enam user, hal ini diperlukan untuk melihat pengaruh yang akan terjadi untuk hasil akhir, apabila user ditambah berikut variasi skenario handover pada Tabel 1 dan Tabel 2. 
Tabel 1 Variasi Skenario Hard Handover

\begin{tabular}{|c|c|c|c|c|c|}
\hline $\begin{array}{c}\text { Kecepatan } \\
(\mathrm{Km} / \mathrm{jam})\end{array}$ & $\begin{array}{c}\text { Jarang Antar } \\
\text { BS }(\mathrm{Km})\end{array}$ & Skenario & \multicolumn{3}{|c|}{ User } \\
\hline 20 & 7 & 1 & 1 & 3 & 6 \\
\hline 45 & 8 & 2 & 1 & 3 & 6 \\
\hline 60 & 6 & 3 & 1 & 3 & 6 \\
\hline
\end{tabular}

Tabel 2 Variasi Skenario Soft Handover

\begin{tabular}{|c|c|c|c|c|c|}
\hline $\begin{array}{c}\text { Kecepatan } \\
(\mathrm{Km} / \mathrm{jam})\end{array}$ & $\begin{array}{c}\text { Jarang Antar } \\
\text { BS (Km) }\end{array}$ & Skenario & \multicolumn{4}{|c|}{ User } \\
\hline 65 & 7 & 1 & 1 & 3 & 6 \\
\hline 85 & 8 & 2 & 1 & 3 & 6 \\
\hline 100 & 9 & 3 & 1 & 3 & 6 \\
\hline
\end{tabular}

Pengujian ini dilakukan untuk mengukur quality of service pada jaringan WiMAX ketika terjadi handover dengan layanan mobile station voice over internet protocol. Hasil yang akan dianalisis yaitu, (1) throughput dalam sebuah jaringan WiMAX adalah bandwidth yang sebenarnya (aktual) yang diukur dengan satuan waktu tertentu dan pada kondisi jaringan tertentu yang digunakan untuk melakukan transfer paket dengan ukuran tertentu [7], perhitungannya menggunakan persamaan (1).

$$
\text { Throughput }=\frac{\Sigma \text { Paket dikirim (bit) }}{\text { Waktu pegiriman paket (s) }} \text { bps }
$$

(2) delay waktu total yang dibutuhkan paket mulai dari dikirim oleh sender sampai diterima oleh receiver. Delay merupakan faktor penting dalam menetukan kualitas VoIP dan merupakan musuh terbesar dalam suatu jaringan VoIP. Semakin besar delay yang terjadi maka akan semakin rendah kualitas VoIP yang dihasilkan [8]. Perhitungannya menggunakan persamaan (2).

$$
\text { Delay Rata-rata }=\frac{\text { TotalDelay }}{\text { TotalPaketterima }}
$$

(3) jitter Jitter merupakan variasi delay antar paket yang terjadi pada jaringan IP. Besarnya nilai jitter akan sangat dipengaruhi oleh variasi beban trafik dan besarnya tumbukan antar paket (congestion) yang ada dalam jaringan IP [8], dan perhitungan menggunakan persamaan (3)

$$
\text { Jitter }=\frac{\text { Total variasi delay }}{\text { Total paket terima }}
$$

\subsection{Implemetasi}

Implementasi sistem pada konfigurasi jaringan WiMAX, secara umum dibagi dua bagian yaitu konfigurasi pendukung dan konfigurasi node. Dimana konfigurasi pendukung akan mendukung sebuah jaringan dalam mengatur kelas quality of service yang digunakan, besaran aliran trafik data yang digunakan, frekuensi kerja, rangging ketika mobile melakukan mobilitasnya serta pembuatan dan penggunaan aplikasi voice over internet protocol pada mobile station, hal ini sesuai kebutuhan dari sebuah jaringan.

Konfigurasi node - node utama dalam jaringan akan berkomunikasi atau saling berhubungan dalam memberikan layanan secara kontinu, untuk memastikan paket data yang dikirim sesuai dengan permintaan. Dalam berkomunikasi server, bacbone, base station dan mobile station akan di berikan IP address, hal ini diperlukan agar pengiriman paket data akan tertuju sesuai dengan yang diharapkan. Dimana permintaan paket dilakukan ketika mobile station pergerakannya dari serving BS hingga BS target untuk melakukan handover disetiap BS target yang dilewati satu arah (one way) berlawanan jarum jam. Pemilihan node base station menggunakan cell hexagonal dikarenakan lebih efektif karena dapat mengatasi blank spot dan overlap covarage dalam sebuah jarigan. Seperti ditunjukkan pada Gambar 4. 


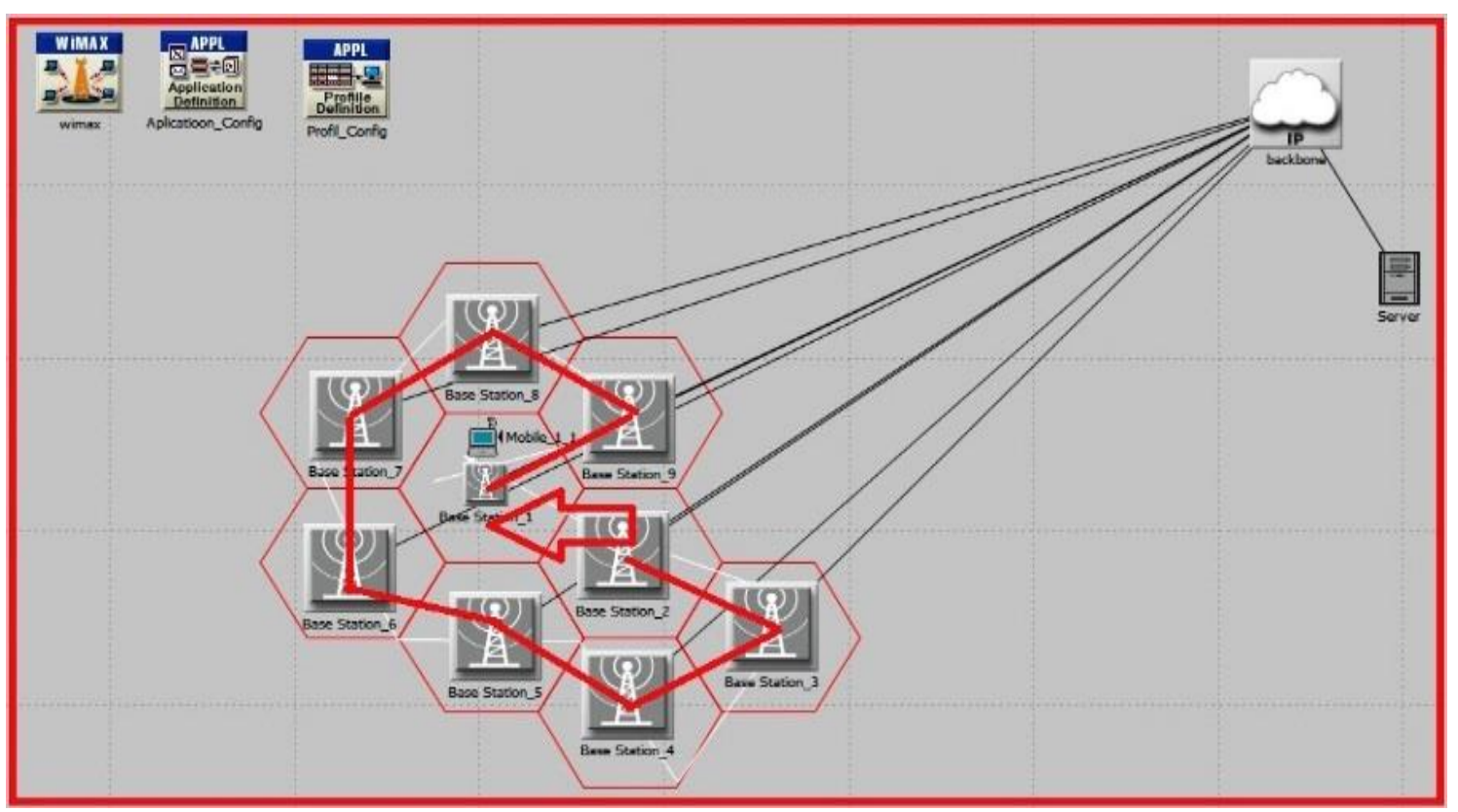

Gambar 4 Implementasi jaringan WiMAX

Kecepatan ketika mobile melakukan mobilitas disetiap skenario akan dibedakan, dengan perlakuan mem-variasikan kecepatan yang dibutuhkan. Skenario low mobility untuk hard handover dan full mobility untuk soft handover. Jarak tempuh antar base station juga divariasikan untuk memudahkan prediksi area handover. Rute yang akan dilewati oleh mobile station akan berlawanan arah jarum jam secara berurutan dalam melewati base station.

\subsection{Pengujian Jitter}

\section{HASIL DAN PEMBAHASAN}

\subsubsection{Hard handover}

Gambar 5 memperlihatkan rata-rata nilai jitter pada jaringan WiMAX dengan user menggunakan aplikasi voice over internet protocol. Berdasarkan hasil simulasi yang telah dilakukan, ketika jumlah user bertambah akan mengalami peningkatan nilai jitter. Hal ini dipengaruhi oleh kepadatan trafik pada jaringan ketika semua user aktif melakukan komunikasi dengan aplikasi VoIP.
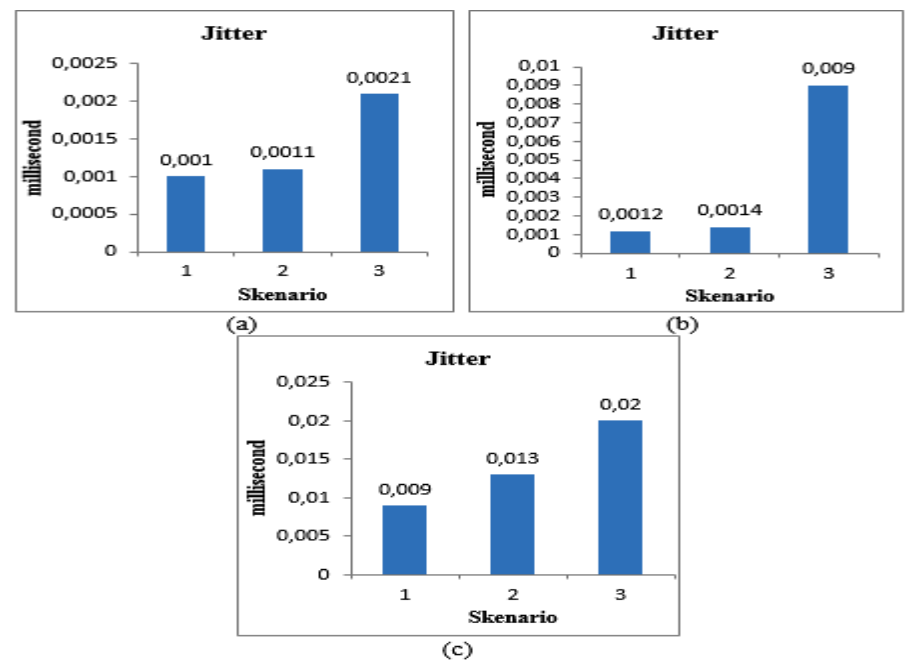

Gambar 5 Jitter Hard Handover : a) 1 User; b) 3 User; c) 6 User 
Dengan running pengujian 20 menit didapatkan hasil rata-rata pada setiap skenario dengan nilai yang bervariasi dalam rentang indeks ke-3 dan masuk dalam katagori degradasi $0 \mathrm{~ms}$ sampai dengan $75 \mathrm{~ms}$. Besaran nilai tertinggi jitter terjadi pada skenario ketiga dengan 6 user yaitu 0.02 seperti Gambar 5c. Besaran paket data yang dikirim akan mendapatkan kualitas tinggi (codec G.711) dan didukung kelas service yang responsif sangat baik untuk aliran trafik real-time. Sehingga sending rate trafik secara konstan disetiap penambahan beban user akan sangat mempengaruhi kualitas jitter pada VoIP.

\subsubsection{Soft Handover}

Kinerja jaringan WiMAX ketika server mengirim paket data menggunakan bandwidth 64 Kbps. Penggunaan bandwidth yang kecil maka congestion dalam jaringan akan dapat dihindari sehingga jitter dapat ditekan. Gambar 6a memperlihatkan pengaruh jitter pada skenario kedua dan terjadi penurunan jitter secara signifikan, hal tersebut akibatkan pada pengujian pertama skenario ke-2 terjadi perbedaan interval waktu yang tidak terlalu lama terhadap pengiriman paket data dan kedatangan paket data. Pada Gambar 6c memperlihat nilai rata-rata jitter dari tiga skenario dengan tiga pengujian, dimana terjadi kenaikan nilai jitter hingga 0.031 pada skenario ketiga, yang diakibatkan oleh banyak user yang menggunakan aplikasi layanan voice over internet protocol secara bersama dalam jaringan yang sama (jaringan WiMAX).
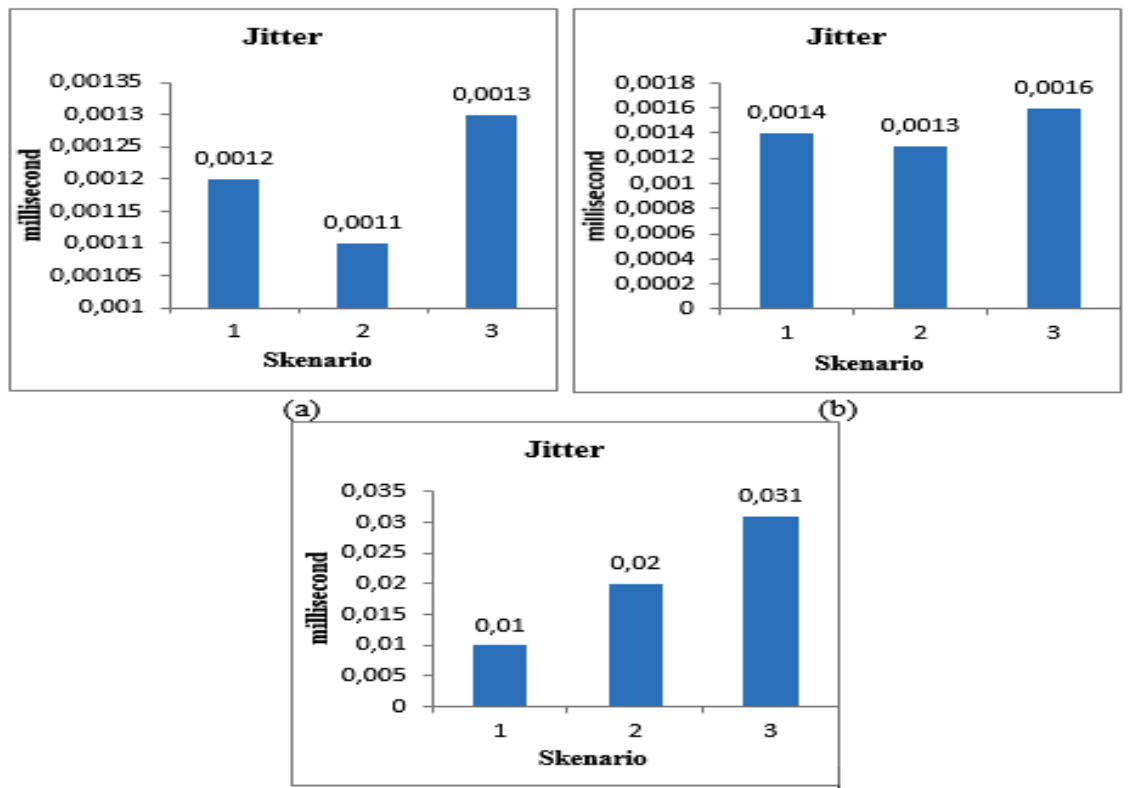

(c)

Gambar 6 Jitter Soft Handover : a) 1 User, b) 3 User; c) 6 User

Pengujian dilakukan untuk mendapat nilai jitter dilakukan one way (satu arah) sesuai rekomendasi ITU-T [5]. Gambar 6 menunjukkan peningkatan nilai jitter rata-rata per skenario untuk setiap pengujian, dimana nilai jitter tertinggi terdapat pada kecepatan user maksimal 100 $\mathrm{Km} / \mathrm{jam}$. Sending rate data untuk aplikasi voice over internet protocol harus selalu kontinu dan konstan, untuk menghindari penurunan quality of service yang berakibatkan tidak maksimalnya kualitas aplikasi.

\subsection{Pengujian Delay}

3.2.1 Hard handover

Skenario pengujian hard handover pada jaringan WiMAX menggunakan bandwidth yang rendah, dengan hasil delay rata-rata yang diperoleh masih dalam tahapan sangat bagus dimana katagori latensi dengan besaran delay $<150 \mathrm{~ms}$. Pada Gambar 7 terjadi peningkatan delay yang diakibatkan oleh propagation delay dimana transmisi melalui jarak antara pengirim (server) dan 
penerima (user) aktif, diakibatkan variasi jarak antar base station (covarage) disetiap skenario yang berbeda. Delay ketika melakukan handover juga diakibatkan oleh processing delay saat sistem melakukan proses coding atau penggabungan data, compression, decompression hingga melakukan decoding atau menguraikan data yang telah digabungkan. Pada Gambar 7b menampilkan rata-rata delay yang terjadi pada pengujian menggunakan metode hard handover dengan nilai delay minimum pada skenario ketiga pengujian ke-2 dengan besaran delay rata rata 10,5 milli detik dengan 3 user aktif.
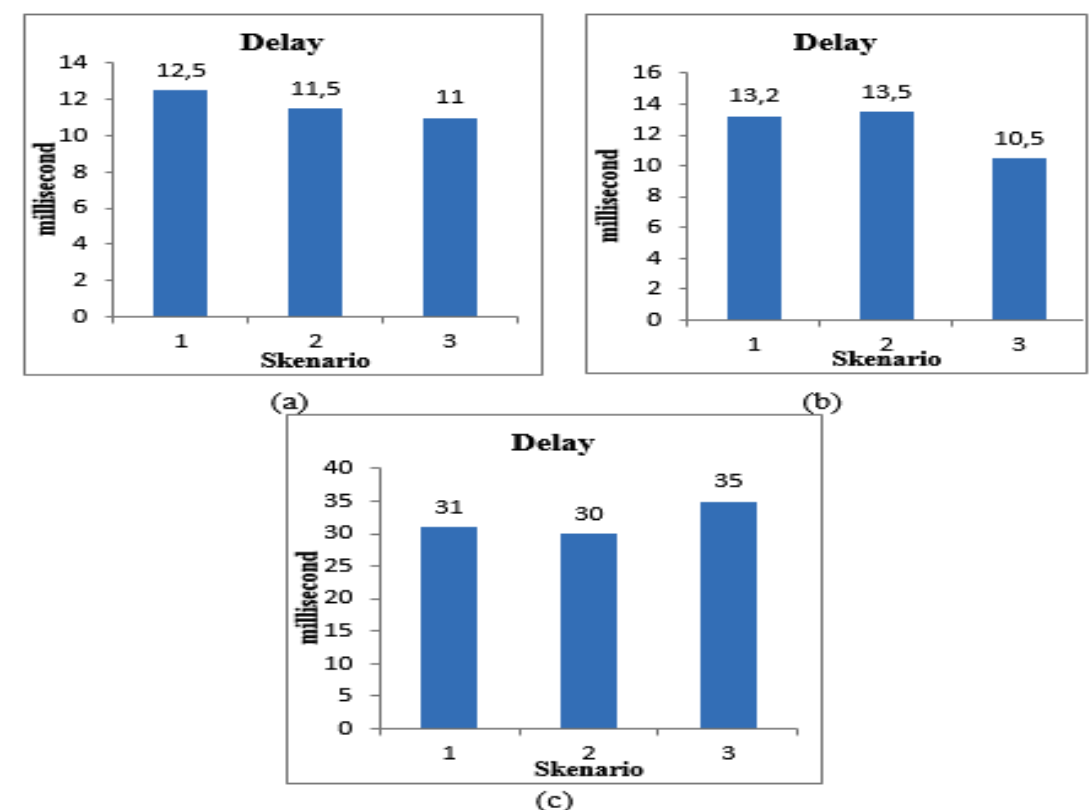

Gambar 7 Delay Hard Handover : a) 1 User; b) 3 User; c) 6 User

Gambar 7c menunjukkan peningkatan delay signifikan terjadi kenaikan hingga $35 \mathrm{~ms}$, peningkatan tersebut terjadi akibat bertambahnya beban user aktif yang berdampak pada waktu tunggu paket sampai dilayani (queuing delay) menjadi terganggu. Gambar 7a menunjukkan delay masih dalam tahap yang sangat bagus dengan perubahan rata-rata delay disetiap kecepatan 11-12,5 ms. Penggunaan codec G.711 dengan proses digitalisasi suara menggunakan PCM akan mempengaruhi nilai delay saat paketisasi digital voice sample (paketization delay) yang pengaruhnya terjadi ketika paket data dikirim melewati jaringan hingga sampai ke user sebagai penerima akhir.

\subsubsection{Soft Handover}

Gambar 8a pengujian menggunakan metode soft handover pada setiap skenario dengan variasi rata - rata delay minimum 10,5 ms terjadi pada skenario pertama, dikarenakan codec G.711 dengan beban 1 user memiliki performa yang lebih baik sehingga menghasilkan delay lebih kecil. Perbedaan delay yang signifikan terajadi pada pengujian selanjutnya, ketika penambahan beban user dilakukan. Sehingga penambahan user tersebut sangat mempengaruhi kualitas output yang dihasilkan. 


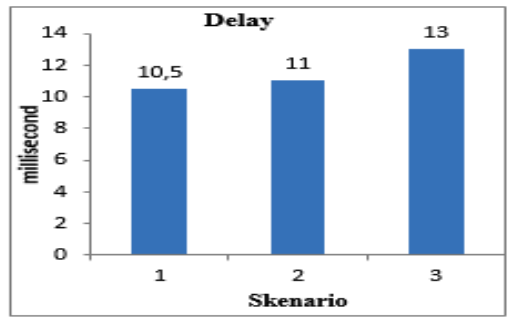

(a)

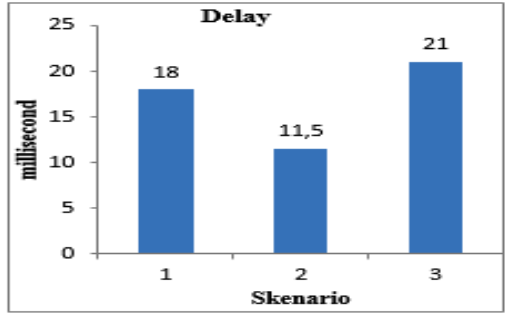

(b)

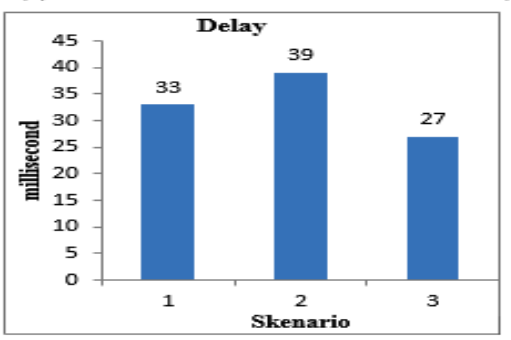

(c)

Gambar 8 Delay Soft Handover : a) 1 User; b) 3 User; c) 6 User

Selain penambahan beban user kenaikan delay yang signifikan terjadi pada Gambar 8c diakibatkan jarak transmisi antara server dan user (propagation delay), karena jarak tempuh yang berbeda antar base station ketika user melakukan mobilitasnya. Delay pada jaringan WiMAX dengan 6 user juga diakibatkan karena waktu yang diperlukan untuk proses pembentukan paket dari informasi user, yang menyebabkan waktu tunggu paket akan dilayani (queuing delay) menjadi lebih lama. Selanjutnya terjadi delay yang diakibatkan adanya buffer untuk mengatasi jitter, ini harus diminimalisasi agar tingkat interaktif dapat dipertahankan, dan menghindari terjadinya jeda yang tidak natural. Gambar 8 menunjukkan nilai rata-rata delay 10,5 - 13 (a), 11,5 - 21 (b) dan 27 - 39 (c) masih dibawah nilai maksimum yang direkomendasikan oleh ETSI [9] untuk aplikasi suara yaitu $150 \mathrm{~ms}$, dan masih bisa diterima pengguna hingga $250 \mathrm{~ms}$.

\subsection{Pengujian Throughput}

Kecepatan transfer data efektif yang diukur dalam bit/detik merupakan jumlah total kedatang paket yang sukses dialiri pada waktu tertentu (throughput), pada skenario handover dengan metode hard handover untuk aplikasi voice over internet protocol. Rekomenasdasi ITU$\mathrm{T}$ [5] untuk mobilitas user searah (one way), dengan frekuensi kerja $2.5 \mathrm{GHz}$ dan service class quality of service menggunakan real-time polling service yang nilai throughput lebih longgar dari kelas service unsolicated grant service. Menurut teori bahwa penggunaan frekuensi yang tinggi akan membutuhkan energi yang lebih untuk memancarkan sinyal dari base station sementara pada percobaan ini variable energy tidak ada (diasumsikan tetap) sehingga penetapan frekuensi kerja $2.5 \mathrm{GHz}$ justru menghasilkan throughput yang lebih kecil. Output pada Gambar 9 dapat dilihat throughput rata-rata per skenario dalam setiap pengujian, hal ini diberpengaruhi kecepatan dan banyaknya user aktif yang melakukan mobilitasnya, dimana ketika mobile station bergerak kecepatan transfer data dari server melewati base station hingga ke user sangat kecil. 

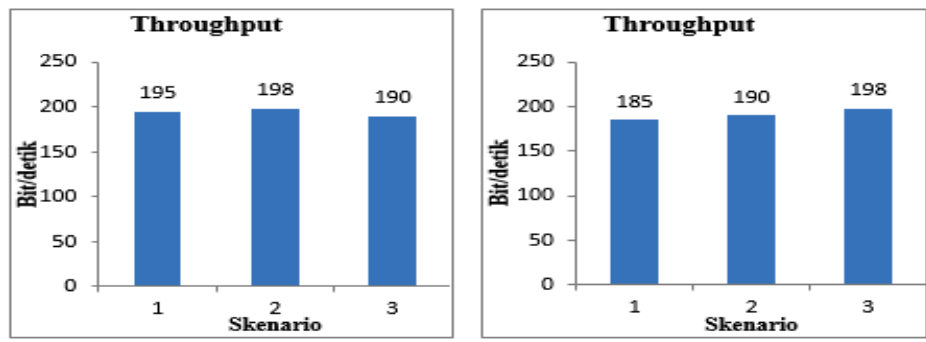

(a)

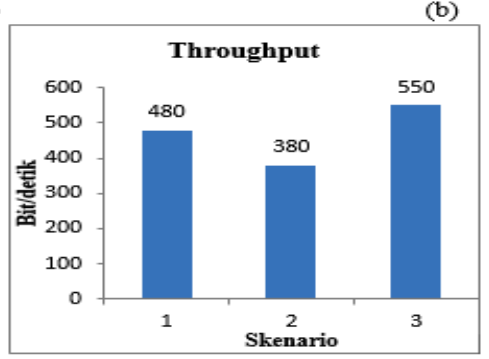

(c)

Gambar 9 Throughput Hard Handover : a) 1 User; b) 3 User; c) 6 User

Berdasarkan output throughtput pada Gambar 9c terjadi kenaikan hasil yang signifikan pada dengan nilai 350 - 550 Bit/detik, akan tetapi hasil ini masih sangat kecil dan mengindikasikan bahwa kecepatan transfer data atau throughput sangat kecil mempengaruhi komunikasi yang menggunakan aplikasi voice over internet protocol.

Selanjutnya hasil throughput rata-rata pada Gambar 10 yang menggunakan metode soft handover dengan aplikasi voice over internet protocol dan frekuensi kerja $2.5 \mathrm{GHz}$ sesuai dengan lisensi yang dikeluarkan WiMAX Forum. Penggunaan channel bandwidth $10 \mathrm{Mhz}$ dan modulasi akan mempengaruhi mempengaruhi jauh tidaknya jarak jangkauan antar base station. Semakin jauh jarak jangkauan maka seharusnya menurunkan nilai throughput, dan hasilnya paket yang dikirimkan memiliki kualitas yang kurang baik jika dibandingkan paket yang dikirim dengan jarak jangkau yang lebih dekat. Gambar 10a hasil rata-rata throughput $180 \mathrm{Bit} / \mathrm{detik}$ $195 \mathrm{Bit} /$ detik masih jauh dari yang diharapkan, dimana throughput dengan 1 user nilai yang dihasilkan masih sangat kecil.
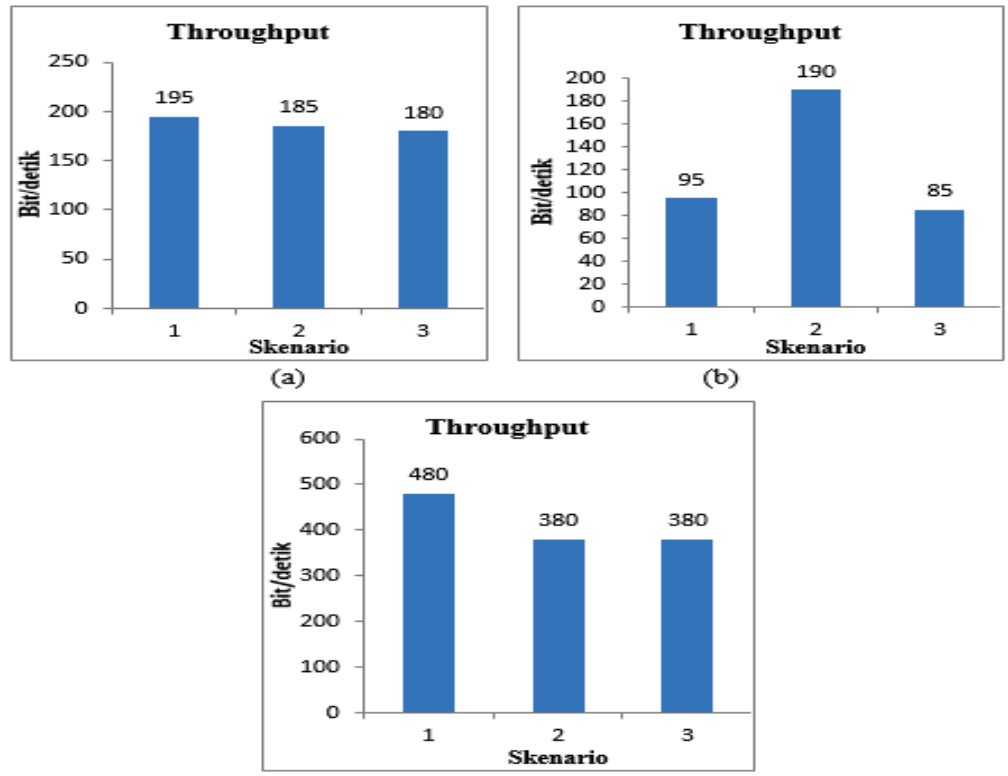

(c)

Gambar 10 Hasil Pengujian Throughput Soft Handover : a) 1 User; b) 3 User; c) 6 User

IJCCS Vol. 10, No. 1, January 2016: $59-70$ 
Gambar 10c menunjukkan nilai throughput yang dipengaruhi oleh penambahan user, kecepatan serta area jangkauan lebih jauh menghasilkan throughput lebih besar. Hal tersebut berbeda dengan teori yang ada dimana seharusnya hasil throughput bisa lebih kecil dari Gambar 10a,b. Dengan hasil throughput tersebut mengindikasikan bahwa aplikasi tersebut tidak sensitif atau berpengaruh terhadap kecepatan transfer data walaupun memakai low bandwidth dengan codec G.711

\section{KESIMPULAN}

Berdasarkan hasil penelitian terhadap jaringan WiMAX menggunakan metode handover khususnya metode hard handover dan soft handover, dengan layanan pada mobile station voice over internet protocol dan disimulasikan memakai optmized network engineering tools, dapat disimpulkan :

1. Pengujian tiga skenario metode hard handover dan soft handover, dilakukan menggunakan tiga kali pengujian dimana terjadi perbedaan interval waktu antara pengiriman paket dan penerimaan paket, dengan besaran trafik yang dikirim $64 \mathrm{Kbps}$ (low bandwidth) congestion dalam jarigan dapat dihindari. Nilai rata-rata jitter $0.001 \mathrm{~ms}-0.02 \mathrm{~ms}$ metode hard handover dan $0.0011 \mathrm{~ms}-0.31 \mathrm{~ms}$ metode soft handover, hasil tersebut tidak menunjukkan perbedaan signifikan terhadap penggujian dua metode handover yang menggunakan aplikasi voice over internet protocol, sehingga mekanisme handover untuk layanan VoIP bekerja efektif dan ideal pada jarigan WiMAX.

2. Pengujian handover menggunakan metode hard handover dan soft handover dengan aplikasi pada user voice over internet protocol. Terjadi kenaikan delay yang signifikan ketika penambahan beban user aktif dilakukan, hal tersebut terjadi pada saat coding atau penggabungan data, compression, decompression, hingga data diurai atau decoding. Nilai rata-rata untuk masing-masing $10.5 \mathrm{~ms}-35 \mathrm{~ms}$ metode hard handover dan $10.5 \mathrm{~ms}-39$ ms soft handover, kenaikan tertinggi delay terjadi setiap pengujian ketiga dengan 6 user aktif. Hasil ini menunjukkan bahwa Aplikasi voice over internet protocol sangat sensitif terhadap delay akan tetapi delay dalam pengujian ini masih dalam batasan toleransi yang diizikan.

3. Pengujian throughput dengan kelas service QoS yaitu service real-time polling service, memakai chanel bandwidth $10 \mathrm{MHz}$ dan frekuensi kerja $2.5 \mathrm{GHz}$. Kecepatan transfer data masih sangat kecil $185 \mathrm{Bit} /$ detik - $550 \mathrm{Bit} /$ detik hard handover dan $85 \mathrm{Bit} / \mathrm{detik}$ - 480 Bit/detik soft handover. Dari hasil tersebut mengindikasikan bahwa throughput tidak mempengaruhi komunikasi menggunakan aplikasi voice over internet protocol.

\section{SARAN}

Adapun saran yang dapat disampaikan untuk penelitian berikutnya:

1. Penelitian selanjutnya sebaiknya dilakukan secara real (nyata), dengan variasi frekuensi band yang berbeda serta fokus bagaimana meminimalkan delay.

2. Perlu penelitian lebih lanjut terhadap dengan menggunakan standar coding dan kompresi dengan memvariasikan method compression yang memakai bandwidth yang berbeda. 


\section{DAFTAR PUSTAKA}

[1] Wibisono, G., Hantoro, G. D., 2006, WiMAX Teknologi Broadband Wireless Access (BWA) Kini dan Masa Depan., Informatika Bandung.

[2] Gurning, R. P., Pinem, M., 2013, Evaluasi Kinerja Algoritma Histeresis Hard Handoff Pada Sistem Seluler., Singuda Ensikom Vol. 3 No. 2. Hal., 46-51.

[3] Gunawan, H., Herlinawati., Komarudin, M., Muhamad., 2012, Simulasi dan Analisis Kualitas Layanan pada Jaringan Mobile WiMAX. Electrician Jurnal Rekayasa dan Teknologi Elektro., Volume: 6 No.3. Hal., 185-181.

[4] Alshomrani. S., Qamar, S., Jan, S., Khan, I., Shah, I.A., 2012, "QoS of VOIP over WiMAX Access Network", International Journal of Computer Science and Telecommunications, vol. 3, no. 4, pp., 92-98.

[5] Munadi, R., 2011, Teknik Switching, Edisi Revisi, Informatika Bandung.

[6] ITU-T., 2003, Transmission Systems and Media, Digital Systems and Networks "One-Way Transmission Time” Recommendation G.114, International Telecommunication Union

[7] Sugeng. W., Istiyanto. J. E., Mustofa. K., Ashari. A., 2015, The Impact of QoS Changes towards Network Performance, International Journal of Computer Networks and Communications Security, ISSN 2410-0595, VOL. 3, NO. 2., pp 48-43.

[8] Cisco., 2004, Voice Over IP guide Enterprise Voice Over Data Design (EVODD), Cisco system, Inc.

[9] ETSI., 1999, Telecommunications and Internet Protocol Harmonization Over Networks (TIPHON); General aspects of Quality of Service (QoS), Technical Report, European Telecommunications Standards Institute. 